\title{
Experiment Start Date
}

National Cancer Institute

\section{Source}

National Cancer Institute. Experiment Start Date. NCI Thesaurus. Code C90487.

The date on which an experiment begins. 